\title{
Experimental Investigation Of The Effect Of Turbulators On Heat Transfer In Horizontal Tubes
}

\author{
Şendoğan Karagöz ${ }^{1}$, Hossein Abdi ${ }^{2}$, Gökhan Ömeroğlu ${ }^{3}$ \\ ${ }^{1,2,3}$ Ataturk University, Faculty of Engineering, Department of Mechanical Engineering, 25240 Erzurum, TURKEY. \\ e-posta: gomeroglu@atauni.edu.tr
}

GelişTarihi: 23.11.2016 ; Kabul Tarihi: 08.08.2017

\begin{tabular}{|c|c|}
\hline & Abstract \\
\hline $\begin{array}{c}\text { Keywords } \\
\text { Turbulator; Heat } \\
\text { Transfer; Pressure }\end{array}$ & $\begin{array}{l}\text { The interest in increasing heat transfer is growing in line with industrial development. In relation to the } \\
\text { cooling and heating systems, in particular in industrial-type boilers, the heating boilers and heat } \\
\text { exchangers, the use of inserts to enhance heat transfer is quite common. During the design of the heat } \\
\text { exchanger while increasing heat transfer, the friction hence the pressure loss will increase as well. As a } \\
\text { matter of course, the cost of increased energy consumption for pumping fluid in tubes should be } \\
\text { compensated with the reduction in cost of the device. }\end{array}$ \\
\hline Drop; Horizontal tube & $\begin{array}{l}\text { In this experimental study, turbulence creating flaps have been placed into the tubes and compared to } \\
\text { the empty tube. Experiments have been carried out using three springs and three twisted tapes having } \\
\text { different pitches, and five different Reynolds numbers. The effects on the friction factor and on the } \\
\text { number of Nusselt were investigated. }\end{array}$ \\
\hline
\end{tabular}

\section{Yatay Borulardaki Isı Transferine Türbülatörlerin Etkilerinin Deneysel Olarak Incelenmesi}

\author{
Anahtarkelimeler \\ Türbülatör; IsI \\ transferi; \\ Basınçdüşümü; \\ Yatayboru
}

\begin{abstract}
Özet
Isı transferini artırmaya olan ilgi endüstriyel gelişme doğrultusunda artmaktadır. Soğutma ve ısıtma sistemleri ile ilişkili, özellikle endüstriyel tip kazanlar, ısıtma kazanları ve ısı eşanjörlerinde, Isı transferin artırmak için türbülatörlerin kullanımı oldukça yaygındır. Eşanjör tasarımında ısı transferini arttırırken , sürtünme dolayısıyla basınç kaybı da artar. Doğal olarak, borulardaki sıvıyı pompalamak için artan enerji tüketiminin maliyeti, cihazın maliyetindeki düşüş ile telafi edilmelidir. Bu deneysel çalışmada türbülans oluşturan kanatlar, tüplere yerleştirildi ve boş tüp ile karşılaştırıldı. Deneyler, farklı aralıklara sahip üç yay ve üç bükülmüş levha ile beş farklı Reynold sayısını kullanarak gerçekleştirildi. Sürtünme faktörü ve Nusselt sayısına etkileri araştırıldı..
\end{abstract}

(C) AfyonKocatepeÜniversitesi

\section{Introduction}

During the design of a heat exchanger, the friction hence the pressure loss will increase while trying to increase heat transfer. As a matter of course, the cost of increased energy consumption for pumping fluid in tubes should be compensated with the reduction in cost of the device. Pumping costs at low speed is so small. However, the heat exchange is sufficiently low to be economical. Therefore, increased speed increases both energy consumption and the heat transfer. One of the passive methods of improving heat transfer is the renewal of the boundary layer. Boundary layer, is related to the flow type, which is thicker in laminar flow and thinner in turbulent flow. Therefore, heat transfer in turbulent flow usually takes place faster than it does in laminar flow. So the thinner the thickness of the boundary layer the more heat transfer between the fluid and the tube will take place (Argunhan and Yıldız, 2006). 
Heat transfer and the effect of vortex in a turbulent air flow on the heat transfer through a tube were investigated experimentally. When compared to heat transfer in non-swirl tube flow; heat transfer in tubes containing a swirl element found to have increased significantly (Sparrow and Chaboki 1984).

The effects of curved strip, placed into a concentrically disposed double-tube heat exchanger, on the heat transfer and pressure loss were examined. Experiments were carried out both for isotropic and opposing flow situations. Heat transfer in double-tube air-cooled systems has been increased by $100 \%$ by inserting curved stripshaped diffusor into the tube (Yıldızet al. 1998).

In another study, fluid vibration characteristics of conical diffusor rings employed to increase the amount of heat transfer in heat exchangers were experimentally investigated. For the increase of Nusselt number with increasing Reynolds number and for the smallest slope embodiment, the maximum amount of heat transfer is obtained (Yakut and Şahin, 2004).

For the in-tube flow; the effect of the use of helical springs of circular cross section on heat transfer was experimentally investigated. The effects of friction factor and performance characteristics of this type of diffusors on heat transfer were studied. Consequently, wire windings have been found to be thermodynamically advantageous for the values of Reynolds number up to 13,000 (Yakut and Şahin, 2004).

Lee and Abdel-Moneim (2001), using CFD models, studied heat transfer and flow behavior in a horizontal channel to one surface of which twodimensional turbulators were mounted. Study was by constant heat flux. The turbulators used were found to significantly enhance heat transfer.

Another study on increasing the amount of heat transfer in a tube on which helical strips have effect was presented by Eiamsa-ard and Promvonge (2005). A helical tape, which produces turbulent flow helping increase the rate of heat transfer, was placed into the tube. Flow having Re values ranging from 2300 to 8800 was used. As a result of experiments; using helical tapes was found to increase the rate of heat transfer compared to empty tube. With regularly disposed helical tapes, an enhancement over almost 50\% compared to empty tube is achieved. For $p=0.5$, the highest Nusselt number was obtained.

Effects of diffusor varieties in turbulent channel flow on heat transfer and flow losses were studied. It has been observed that the average heat transfer increased by $16-19 \%$ when the ratio of channel area to diffusor area equals to 30 and the performance of rectangular diffusors were better (Zhu, Mitra and Fiebig, 1993).

Conical surface ring diffusors placed at tube inlet found to have increased the friction factor 9-folds while increased heat transfer by $75 \%$ (Küçük et al. 2000).

In the heat exchangers with nested tubes; the effect of rotation on Nusselt number and pressure drop was investigated by turning the inner tube. The study showed that the Nusselt number of the rotating helical inner tube was a few times greater than that of the smooth surfaced tube. Also, it was determined that the additional pressure drop has left small in comparison with the increase in heat transfer (Yıldız et al.1996).

In this paper, the effects of diffusors on heat transfer in horizontal tubes were experimentally examined and the results are presented. Nusselt vs. Reynolds and friction vs. Reynolds graphics were obtained. The effect of improving heat transfer was investigated in this study during which heat transfer enhancement turbulators were used.

\section{Experimental Set-up and Experimental Method}

\subsection{Experimental Set-up}

Experimental setup consists of two basic parts, fluid supply section and test section. The functionality of all elements and measuring devices in the system was tested and calibration of measuring devices has been made (Fig. 2.1).

Fluid Supply Section 
Fluid supply section is composed of pump, flow rate regulating valve, stabilizing tank, flow meter and a heat exchanger that is used to keep fluid entering the system at a certain temperature. Fluid supply section ensures that water is brought to tube inlet conditions.

\section{Test Section}

Test section is where single phase flow occurs. Test section consists of; fluid inlet control valve, heater test tube, a $40 \mathrm{~kW} \mathrm{DC}$ power supply that supplies required power to the heater test tube, bourdon type pressure gauge, thermocouple and pressure transducer. At test tube portion, located bourdon type pressure gauge, pressure transducers and temperature measuring element. Bourdon type manometer measured the pressure of the system. The pressure transducers employed at inlet and outlet of the system were used to measure the pressure loss. Five different flow rates were used in experimental studies (205-307-409-511-615 I/hour). Inlet temperature of the fluid before entering the test section was measured by a T-type thermocouple.

Test tube is a $\mathrm{Cr}-\mathrm{Ni}(316 \mathrm{~L})$ tube with a length of $1020 \mathrm{~mm}$, outer diameter of $17 \mathrm{~mm}$ and inner diameter of $12.7 \mathrm{~mm}$. Out of 24 pieces $0.25 \mathrm{~mm}$ diameter copper-constantan

T-type thermocouples; 22 employed to measure the surface temperature of the test tube and 2 to measure inlet and outlet fluid temperatures. Of thermocouples attached to the test tube wall; 11 were fastened to the top wall and 11 to the bottom wall, all arranged at equal intervals at the outer surface of the test tube.

6 different heat transfer surface configurations were used in order to determine the effect of enhancement of heat transfer through horizontal tubes. Heat transfer surfaces and their characteristics are given in Table 2.1 and Fig. 2.2 shows images of heat transfer enhancement turbulators.

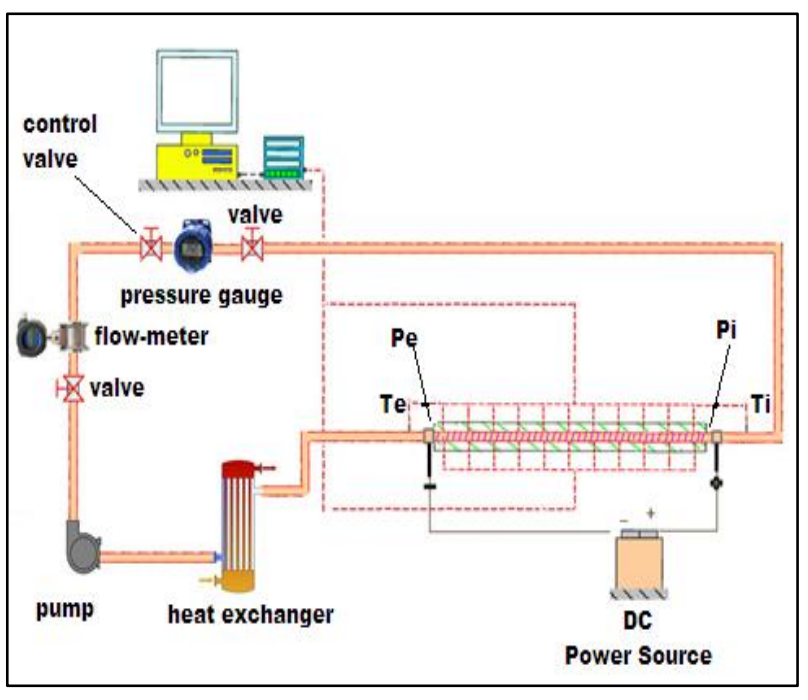

Figure 2.1. Schematic view of experimental set-up

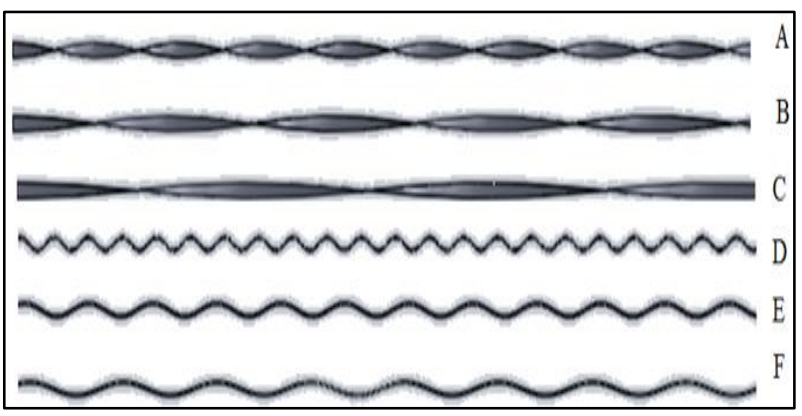

Figure 2.2. Heat transfer enhancement turbulators

As shown in Table 2.1, heat transfer surfaces are characterized by effective diameter. Effective diameter is calculated using the following equation.

$$
d_{e}=\sqrt{\frac{4 \mathrm{~V}^{\prime}}{\pi \mathrm{L}}}
$$

Whereas $\mathrm{V}^{\prime}$ is net internal volume of tube, and $\mathrm{L}$ is the length of tube. 
Table 2.1. Heat transfer surface configurations and characteristics

\begin{tabular}{lll}
\hline Code & Definition & $\begin{array}{l}\text { Effective } \\
\text { Diameter }\end{array}$ \\
\hline X & Empty tube & $12.7 \mathrm{~mm}$ \\
A & Strip having $115 \mathrm{~mm}$ pitch & $12.31 \mathrm{~mm}$ \\
B & Strip having $215 \mathrm{~mm}$ pitch & $12.32 \mathrm{~mm}$ \\
C & Strip having $315 \mathrm{~mm}$ pitch & $12.33 \mathrm{~mm}$ \\
D & Spring having $23 \mathrm{~mm}$ pitch & $12.35 \mathrm{~mm}$ \\
E & Spring having $43 \mathrm{~mm}$ pitch & $12.49 \mathrm{~mm}$ \\
F & Spring having $63 \mathrm{~mm}$ pitch & $12.63 \mathrm{~mm}$ \\
\hline
\end{tabular}

Studies on the establishment of the experimental system can be summarized as follows:

A $1020 \mathrm{~mm}$ long, $12.7 \mathrm{~mm}$ in diameter steel tube made of $\mathrm{Cr}-\mathrm{Ni}$ (316L stainless steel) was used as the test tube in the system.

Stabilizing tank is made of such material durable to required operating pressure.

Power supply, is used to provide the required thermal energy in the heater test tube.

Pressure extruder was used to ensure the required test pressure in the system. Differential pressure meter connected to the inlet and outlet is used to measure the pressure differential.

(1) A magnetic flow meter was mounted to the system for measuring the flow rate of fluid entering the system.

(2) Data received from thermocouples, pressure transducers and turbine type flow meter was transferred to the computer via Advantech brand PC-lab card.

(3) One pump was employed for the purpose of circulating water in the system

(4) One heat exchanger was used in the test tube to ensure that water entered at desired temperature.

\section{Calculation Method}

Nusselt number ( $\mathrm{Nu}$ ), the friction factor (f) and Reynolds Number ( $R e$ ) is calculated using the data obtained experimentally.
Accordingly, the heat supplied to the system, voltage and current of the DC power supply were read directly. The heat is provided by mounting the positive and negative poles of the DC power supply to the input and output of the test probe. Thanks to these poles, electricity is supplied to the test tube. The fact that the test tube is $\mathrm{Cr}-\mathrm{Ni}$ allows the electric current supplied to the system to turn into heat (Figure 2.1).Here from the amount of heat supplied to the system can be calculated using following formula;

$$
Q=V I \sqrt{3}
$$

Likewise; the heat transferred to the fluid from the surface can be expressed as;

$$
Q=h A(T w-T s)
$$

Whereas; $A$ is the inner surface area of the tube; Ts, the average temperature of the water expressed as ((Ti + Te) / 2); and $\mathrm{Tw}$ is the average of wall temperatures measured from 22 points of the tube wall. With the help of heat transfer coefficient obtained from above expression; Nusselt Number is determined using;

$$
N u=\frac{h D}{k}
$$

Whereas $D$ is the diameter of the inner tube, and $k$ is the thermal conductivity coefficient of water. Friction factor (f) was practically expressed as;

$$
\Delta P=f \frac{L}{D}\left(\frac{1}{2} \rho V^{2}\right)
$$

And Reynolds number can be found by below correlation.

$$
\operatorname{Re}=\frac{\rho V D}{\mu}
$$

Whereas $\mathrm{V}$ is characteristic fluid velocity, $\mathrm{D}$ is characteristic diameter, $\mu$ is fluid viscosity, and $\rho$ is the fluid density. 


\section{Results and Discussion}

In this section, findings obtained in experimental studies were evaluated and results were prepared in a graphical environment. Results were examined into two sub-sections, flow in an empty tube and flow in tubes in which enhancement turbulators were used.In this study, it is seen that the spring element turbulators are more efficient than the twisted element turbulators. In subsequent studies, testing of the smaller steps with twisted turbulators would produce different results.The effects of the turbulators with different steps on the heat transfer were investigated, and especially the turbulence in the form of $63 \mathrm{~mm}$ spring and $215 \mathrm{~mm} \mathrm{~B}$ twisted were found to have equal $\mathrm{Nu}$ numbers in all Reynolds numbers. However, the $f$ values differed significantly. The turbulator with the $63 \mathrm{~mm}$ nominal $\mathrm{f}$ value is a very low value, which means lower pumping power. This is one of the most important results of this study.

\subsection{Flow in Empty Tube}

Figure 4.1 shows experimental results obtained from flow in empty tube. As Fig. 4.1 suggests, obtained results are in concordance with results given in the literature. Increase of Nusselt number with increasing Reynolds number is what was expected. Correlation for Nusselt number obtained for experimental operating conditions is $\mathrm{Nu}=0,0151 \cdot \mathrm{Re}^{0,8067} \operatorname{Pr}^{(1 / 3)}$. When compared to the following correlation; this correlation is deemed to be appropriate in terms of Engineering.

$$
\begin{array}{ll}
\text { Colburn } & : \mathrm{Nu}=0,023 \cdot \operatorname{Re}^{0,8} \cdot \operatorname{Pr}^{1 / 3} \\
\text { Dittus-Boelter } & : \mathrm{Nu}=0,023 \cdot \operatorname{Re}^{4 / 5} \cdot \operatorname{Pr}^{0,3}
\end{array}
$$

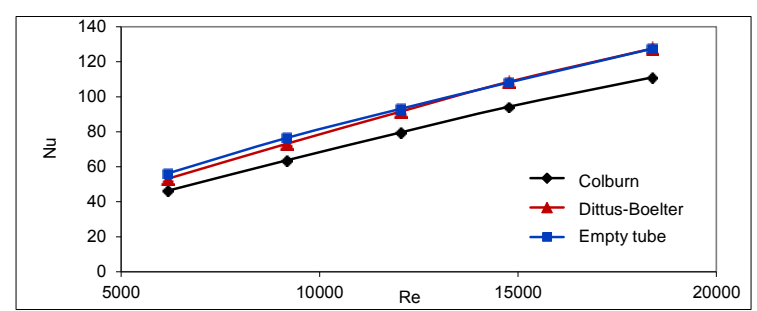

Figure 4.1. Nu-Re variation for empty tube

Experimental results obtained from empty tube are shown in Fig. 4.2. Fig. 4.2 also suggests that f-Re relations are in compliance with those in the literature. Reduction in $f$ with the increase in Reynolds number was an expected result. In Fig. 4.2 , it was observed that the initial values were greater than Blasius equation. The reason for this was due for the inability to precisely read the pressure drop values in low speed. Furthermore, when considered that precision in Blasius equation is $25 \%$, this error level is normal to be expected.

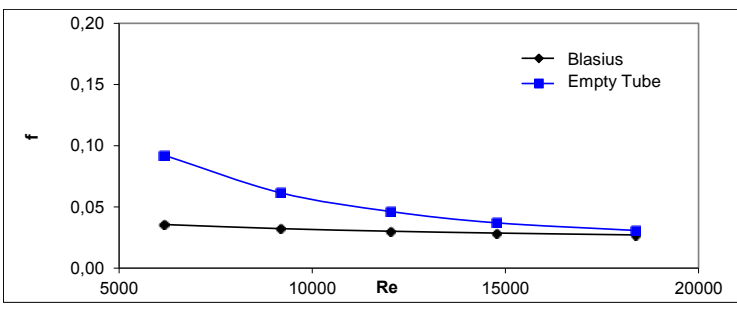

Figure 4.2. f- Re variation for empty tube

\subsection{Flow in Tubes Having Diffusors}

As seen in Fig. 4.3, Nu-Re variations for empty tube and three spring-shaped diffusors having different pitchs are provided. With diffusor having $23 \mathrm{~mm}$ pitch; for all Reynolds numbers the highest Nusselt numbers are obtained. When ordered by Nusselt number, $\mathrm{Nu}_{23 \mathrm{~mm} \text { spring }}>\mathrm{Nu}_{43 \mathrm{~mm} \text { spring }}>\mathrm{Nu}_{63 \mathrm{~mm} \text { spring }}>$ $\mathrm{Nu}_{\text {empty tube }}$ is observed. When all diffusors were compared, Nusselt numbers are also increasing with increasing Reynolds number. This is because of the formation of turbulence in the tube and the resulting increase in the number of $\mathrm{Nu}$ (Guo, Fan, Zhang and Liu, 2011).

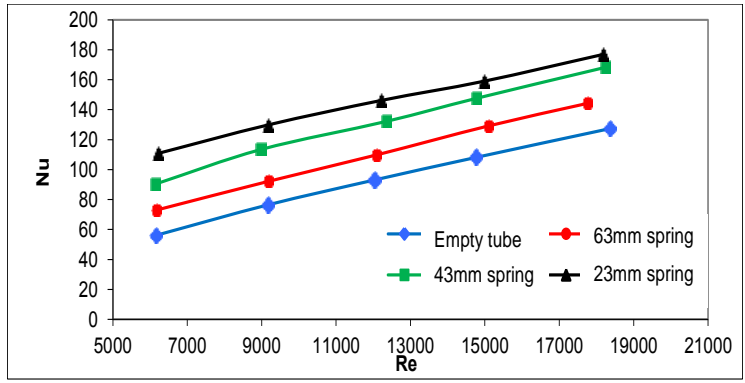

Figure 4.3. Nu-Re variation of spring-shaped diffusors compared to empty tube 


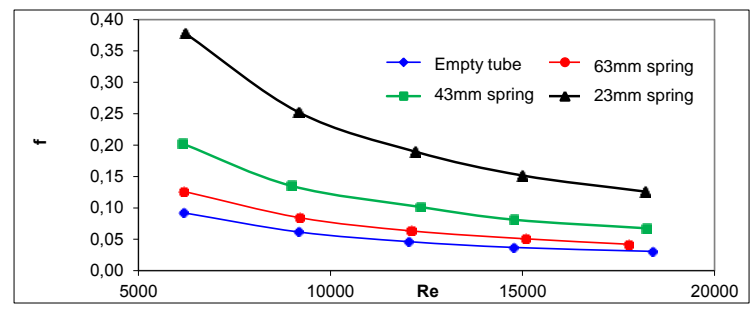

Figure 4.4. f-Re variation of spring-shaped diffusors compared to empty tube

In Figure 4.4, provided are variation of friction coefficient against Re for empty tube and three spring-shaped diffusors having different pitches. A certain increase in friction coefficient is observed when each diffusor inserted were compared to empty tube. Spring-shaped diffusor having $23 \mathrm{~mm}$ pitch had the greatest friction coefficient for all Reynolds numbers. When ordered by friction coefficient, $f_{23 \mathrm{~mm} \text { spring }}>f_{43 \mathrm{~mm} \text { spring }}>f_{63 \mathrm{~mm} \text { spring }}>$ $f_{\text {empty tube }}$ is observed. The increase of the pitch of spring led the formation of turbulence which leads the liquid to more contact tube wall and increased f.

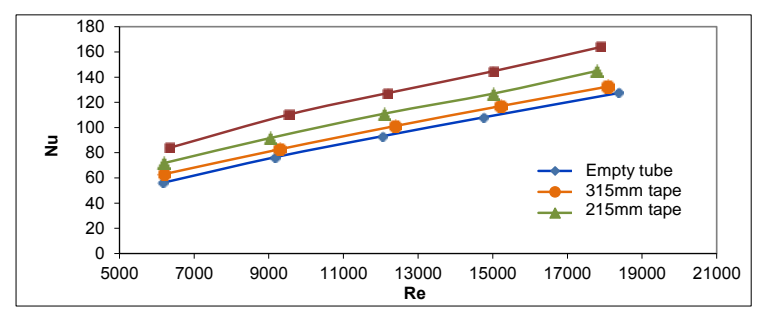

Figure 4.5. Nu-Re variation of twisted-tape-shaped diffusor compared to empty tube

In Fig. 4.5, provided are variation of $\mathrm{Nu}$ against $\mathrm{Re}$ for empty tube and three twisted-tape-shaped diffusors having different pitches. For diffusor having $115 \mathrm{~mm}$ pitch; greatest Nusselt numbers were obtained for all Reynolds numbers. When ordered by Nusselt numbers, $\mathrm{Nu}_{115 \mathrm{~mm} \text { twisted-tape }}>$

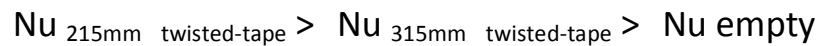
tube is observed. When all diffusors were compared, Nusselt numbers are also increasing with increasing Reynolds number. This is because of the formation of turbulence in the tube and the resulting increase in the number of $\mathrm{Nu}$ (Eiamsa-ard S., Thianpong and Eiamsa-ard P., 2010).

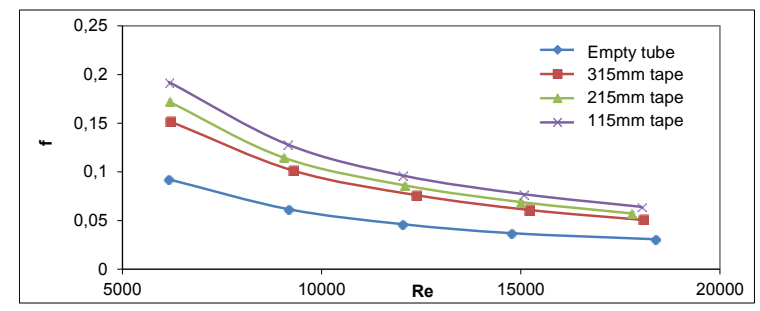

Figure 4.6. $\mathrm{f}$-Re variation of twisted-tape-shaped diffusors compared to empty tube

Figure 4.6, provided are variation of friction coefficient against Re for empty tube and three twisted-tape-shaped diffusors having different pitches. A certain increase in friction coefficient is observed when each diffusor inserted were compared to empty tube. Diffusor having $115 \mathrm{~mm}$ pitch had the greatest friction coefficient for all Reynolds numbers. When ordered by friction coefficient, $f_{23 \mathrm{~mm} \text { twisted-tape }}>\mathrm{f}_{43 \mathrm{~mm} \text { twisted-tape }}>\mathrm{f}_{63 \mathrm{~mm}}$ twisted-tape $>f_{\text {empty tube }}$ is observed. The increase of the pitch of tape led the formation of turbulence which leads the liquid to more contact tube wall and increased $f$.

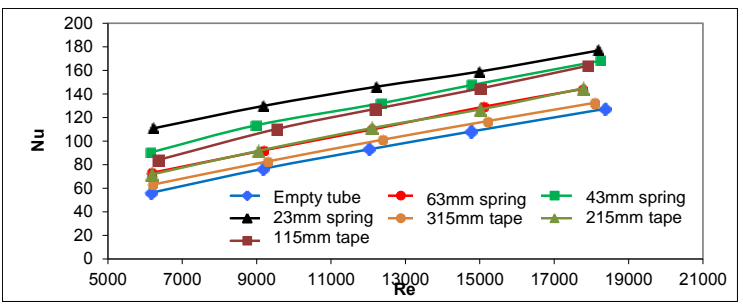

Figure 4.7. Nu-Re variation of twisted-tape-shaped and spring-shaped diffusors compared

In Fig. 4.7, provided are Nu-Re variation of twistedtape-shaped and spring-shaped diffusors. Highest Nusselt number was obtained with spring-shaped diffusor having $23 \mathrm{~mm}$ pitch for all Reynolds numbers. When ordered by Nusselt numbers, $\mathrm{Nu}$ $23 \mathrm{~mm}$ spring $>\mathrm{Nu}_{43 \mathrm{~mm} \text { spring }}>\mathrm{Nu}_{115 \mathrm{~mm} \text { twisted-tape }}>\mathrm{Nu}_{63 \mathrm{~mm}}$ spring $=\mathrm{Nu}_{215 \mathrm{~mm} \text { twisted-tape }}>\mathrm{Nu} 315 \mathrm{~mm}$ twisted-tape is observed. For all Reynolds numbers, almost equal numbers of $\mathrm{Nu}$ is observed for both $215 \mathrm{~mm}$ pitched twisted-tape and $63 \mathrm{~mm}$ pitched spring. 


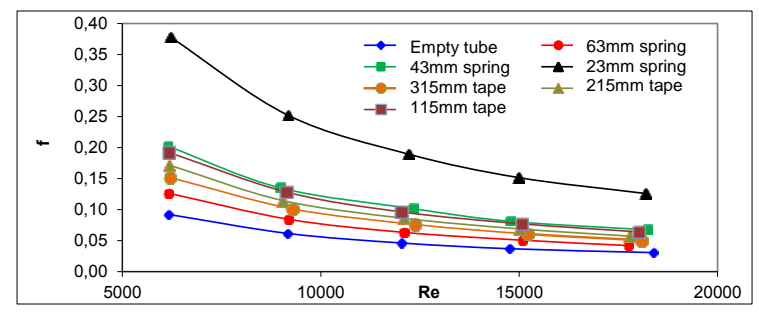

Figure 4.8. f-Re variation of twisted-tape-shaped and spring-shaped diffusors compared

In Fig. 4.8 provided is variation of friction coefficient against Reynolds number for springshaped and twisted-tape-shaped diffusors. $23 \mathrm{~mm}$ pitched spring-shaped diffusor had the greatest friction coefficient for all Reynolds numbers. When ordered by $f ; f_{23 \mathrm{~mm} \text { spring }}>f_{43 \mathrm{~mm} \text { spring }}>f_{115 \mathrm{~mm} \text { twisted- }}$ tape $>f_{215 m m}$ twisted-tape $>f_{315 \mathrm{~mm} \text { twisted-tape }}>f_{63 \mathrm{~mm} \text { spring }}$ is observed. Herein observed, increase in pitch of both springs and twisted-tapes led to formation of turbulence which leads the liquid to more contact tube wall and increased $f$.

\section{Conclusions}

In this experimental study, six different type of fins which would create turbulence in the flow were inserted into the tubes and experiments were carried out for constant heat flux for five different Reynolds numbers ( $R e$ ) to examine the friction coefficient (f) and Nusselt number (Nu). Results are given itemized below;

(1) The correlation of number of Nu obtained in experimental studies is in concordance with those in the literature.

(2) With $23 \mathrm{~mm}$ pitched spring-shaped diffusor, greatest Nusselt numbers were obtained for all Reynolds numbers. When Nusselt numbers for empty tube and spring-shaped diffusors are put in order;

(3) $\mathrm{Nu} 23 \mathrm{~mm}$ spring $>\mathrm{Nu}_{43 \mathrm{~mm} \text { spring }}>\mathrm{Nu}_{63 \mathrm{~mm}}$ spring $>\mathrm{Nu}_{\text {empty tube }}$ is observed.

(4) When all diffusors compared to empty tube, Nusselt numbers were also increasing with increasing Reynolds number.

(5) $23 \mathrm{~mm}$ pitched spring-shaped diffusor had the greatest friction coefficient for all Reynolds numbers. When ordered by $f$; $f_{23 \mathrm{~mm} \text { spring }}>f_{43 \mathrm{~mm} \text { spring }}>f_{63 \mathrm{~mm} \text { spring }}>f_{\text {empty }}$ tube is observed.
(6) $115 \mathrm{~mm}$ pitched twisted-tape-shaped diffusor had greatest Nusselt numbers for all Reynolds numbers. When ordered buNusselt number, $\mathrm{Nu}_{115 \mathrm{~mm}}$ twisted-tape $>$ $\mathrm{Nu}_{215 \mathrm{~mm}}$ twisted-tape $>\mathrm{Nu}_{315 \mathrm{~mm}}$ twisted-tape $>$ $\mathrm{Nu}$ empty tube is observed.

(7) When each diffusor inserted was compared to empty tube, a certain increase in friction coefficient is observed.

(8) $115 \mathrm{~mm}$ pitched twisted-tape-shaped diffusor had greatest friction coefficient for all Reynolds number. When ordered by $f$, $f_{115 \mathrm{~mm} \text { twisted-tape }}>f_{215 \mathrm{~mm} \text { twisted-tape }}>f_{315 \mathrm{~mm}}$ twisted-tape $>f_{\text {empty tube }}$ is observed.

(9) When analyzed in terms of types of diffusors; it is observed that spring-shaped diffusor having $23 \mathrm{~mm}$ pitch had greatest Nusselt number for all Reynolds numbers. When ordered by $\mathrm{Nu}$; $\mathrm{Nu}_{23 \mathrm{~mm}}$ spring $>\mathrm{Nu}_{43 \mathrm{~mm}}$ spring $>\mathrm{Nu}_{115 \mathrm{~mm} \text { twisted-tape }}>$ $\mathrm{Nu}_{63 \mathrm{~mm} \text { spring }}=\mathrm{Nu}_{215 \mathrm{~mm} \text { twisted-tape }}>\mathrm{Nu}_{315 \mathrm{~mm}}$ twisted-tape $>\mathrm{Nu}_{\text {empty tube }}$ is observed.

(10) $215 \mathrm{~mm}$ pitched twisted-tape and $63 \mathrm{~mm}$ pitched spring had almost equal numbers of $\mathrm{Nu}$ for all Reynolds numbers. $63 \mathrm{~mm}$ pitched spring is preferable for lower friction coefficient.

(11) $23 \mathrm{~mm}$ pitched spring-shaped diffusor had greatest friction coefficient for all Reynolds

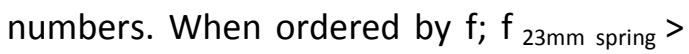
$f_{43 \mathrm{~mm} \text { spring }}>f_{115 \mathrm{~mm} \text { twisted-tape }}>f_{215 \mathrm{~mm} \text { twisted- }}$ tape $>f_{315 \mathrm{~mm}}$ twisted-tape $>f_{63 \mathrm{~mm}}$ spring is observed.

\section{Nomenclature:}

$\mu \quad$ fluid viscosity $(\mathrm{kg} / \mathrm{m} . \mathrm{s})$

$V \quad$ fluid velocity $(\mathrm{m} / \mathrm{s})$

$f \quad$ Friction factor

D Diameter $(\mathrm{mm})$

$\rho \quad$ Fluid density $\left(\mathrm{g} / \mathrm{cm}^{3}\right)$

Re Reynolds Number

$V^{\prime} \quad$ Internal volume of tube $(\mathrm{mm})$

L Length of tube(mm) 
$d_{e} \quad$ Effective diameter $(\mathrm{mm})$

V Voltage (Volt)

$T_{s} \quad$ Average temperature of the water $\left({ }^{\circ} \mathrm{C}\right)$

$T_{w} \quad$ Average of wall temperatures $\left({ }^{\circ} \mathrm{C}\right)$

I Direct current (Amper)

$Q \quad$ Amount of heat $\left(\mathrm{W} / \mathrm{m}^{2}\right)$

$h \quad$ Heat transfer coefficient for convection $\left(\mathrm{W} / \mathrm{m}^{2} k_{\mathrm{Sp}}\right.$

Cr-Ni Chromium-nickel steel tube

$\mathrm{Nu} \quad$ Nusselt number

Pr Prandtl number
$\Delta P \quad$ Differential pressure $(P a)$

$k \quad$ Heat transfer coefficient for conduction (W/m K

Küçük, H., Bali, T., Ayhan, T., 2000.Experimental Investigation of Effects of Helical Inserts with Conical Surface Placed at Pipe Inlet on Heat Transfer and Friction Coefficient. Proc.: Turkish National Conference on Thermal Sciences and Technologies (ULIBTK), Sakarya, 741-745.

Lee, C. K. and Abdel-Moneim, S. A., 2001. Computational Analysis of Heat Transfer in Turbulent Flow Past a Horizontal Surface with TwoDimensional Ribs,Int. Comm. Heat Mass Transfer, 28:2, 161-170.

Sparrow, E. M. and Chaboki, A., 1984. Turbulent Fluid Flow and Heat Transfer in a Circular Tube,ASME Journal of Heat Transfer, 106, 766-773.

Yakut, K. and Sahin, B., 2004. The Effects of Vortex Characteristics on Performance of Coiled Wire $K^{T}$ urbulators Used for Heat Transfer Augmentation,Applied Thermal Engineering, 24, 2427-2438.

\section{References}

Argunhan, Z. and Yildiz, C., 2006. DaireselKesitliBirBorununGirişineYerleştirilenDelikli SabitKanatçıklıDönmeÜreticinin GeçişiveBasınçDüşüşüneEtkileri, PamukkaleUniversty Engineering FakültesiMühendislikBilimleriDergisi, 12 (2), 217223.

Eiamsa-ard, S. and Promvonge, P., 2005. Enhancement of Heat Transfer in a Tube with Regularly spaced Helical Tape Swirl Generators,Solar Energy, 78, 483-494.

Eiamsa-ard, S., Thianpong, C., Eiamsa-ard, P., 2010. Thermal Characteristics in a Heat Exchanger Tube Fitted with Dual Twisted Tape Elements in Tandem,Int. J. Heat Mass Transfer, 37:1, 39-46.

Guo, J., Fan, A., Zhang, X., Liu, W., 2011. A numerical study on heat transfer and friction factor characteristics of laminar flow in a circular tube fitted with center-cleared twisted tape,International Journal of Thermal Sciences, 50:7, 1263-1270.
Yıldız, C., Biçer, Y., Pehlivan, D., 1996. Influence of Fluid Rotation on The Heat Transfer and Pressure Drop in Double-Pipe Heat Exchangers,Applied Energy, 54, 49-56.

Yıldız, C., Biçer, Y., Pehlivan, D., 1998. Effect of Twisted Strips on Heat Transfer and Pressure Drop in Heat Exchanger, Energy Conversion \& Management, 39, 331-336.

Zhu, J. X., Mitra, N. K.,Fiebig, M., 1993.Effects of Longitudinal Vortex Generators on Heat Transfer and Flow Loss in Turbulent Channel Flows,Int. J. Heat Mass Transfer, 36:9, 2339-2347. 